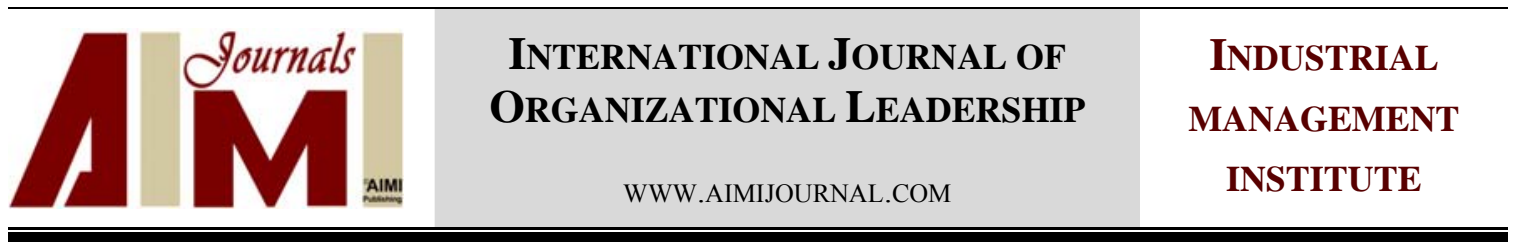

\title{
Designing a model of organizational agility: A case study of Ardabil Gas Company
}

\author{
Behrooz Razmi ${ }^{1}$, Hossein Mohammad Ghasemi ${ }^{2}$ * \\ ${ }^{1}$ Associate professor, Department of Management, Science and Research Branch, Islamic Azad University, Ardabil, \\ Iran \\ ${ }^{2}$ Department of Management, Ardabil Branch, Islamic Azad University, Ardabil, Iran
}

\begin{abstract}
Keywords:

Organizational Citizenship Behavior, Political Skills, Organizational

Commitment, Occupational Self-Efficacy

Correspondence:

h.mghasemi@yahoo.com

Organizational agility means the ability of every organization in sensation, perception, and prediction of available changes in the business environment. The importance of organizational agility in a competitive environment is nowadays widely recognized and accepted. The aim of this research was to design a unified theoretical model of organizational agility for Ardabil Gas Company based upon the theoretical principles of organizational agility proposed by Goldman (1995). Independent variables including organizational intelligence, organizational commitment, and organizational trust were considered as mediator variable and other four essential components of organizational agility such as forming of virtual participation valorize to humanistic knowledge and skills, change readiness, and customers answering were known as dependent variables of research. This is an applied, descriptive-correlation research, conducted by survey methodology. In this study, 568 employees, contractors, and subscribers of Ardabil Gas Company were chosen as the statistical population of the study. For the purpose of the study a questionnaire for data collection was used. Using Structural Equation Modeling (SEM), it is straightforward to test hypotheses of the equality of various correlation coefficients with any number of covariates across multiple groups. The gathered data was analyzed by using SPSS and LISREL software packages. The results of statistical analysis indicate that organizational trust has a significant positive relationship with organizational agility and organizational trust is the moderator of the relationship between technology intelligence and organizational agility and the relationship between organizational commitment and organizational agility.
\end{abstract}




\section{Introduction}

The twenty-first century brings with it rapid and dramatic changes in manufacturing and service sectors of organizations have undergone dramatic changes about themselves. The intensity of these changes has faced these organizations with new challenges (Zain, Rose, Abdullah, \& Masrom, 2005). Agility is known as one of the most important characteristics of organizations in standing out against market turbulences. Organization agility as a cultivated capability allows the organization to make timely, efficient, rapid, and continual change when changing circumstances require it. Also known as a necessary dynamic capability, agility represents the capacity to sense, shape, and seize opportunities and threats, solve problems, and change the firm's resource base (Eisenhardt \& Martin, 2000; Winby \& Worley, 2014). The dynamic capabilities' patterns change with market dynamism. This means that organizational agility is not an on or off switch and any organizations can have it to a certain level (Nijssen \& Paauwe, 2012). Agility is the result of alertness to comprehensive changes both in internal and external environments (Grant, 1996). It implies that agility refers to the capacity to use the available resources in a sustainable manner to meet the changes in a suitable time and in a flexible way that the organization can run it. In today's modern environment, each agile organization should have the power of producing different short life cycle products at the same time, redesigning its everyday products, changing the production method, reacting efficiently to changes. These organizations develop the skills and knowledge, organizational systems and architecture, and necessary experience to execute the existing strategy as well as the ability to design and support potential new capabilities (Winby \& Worley, 2014).

Gas Company as one of servicing companies in Ardabil has encountered with challenges and there is a need for more ongoing research for the purpose of continual service improvement. This research has done with the aim of designing an organizational agility model by considering the role of dependent, mediator, and independent variables. Ardabil Gas Company is considered as one of the companies that plays a vital role in the peoples' life and faced with challenges such as rising expectations of users and subscribers of natural gas, environmental responsibilities, resource constraints, income changes, job skills, rising costs, existing provisions and instructions for informal employees, and increasing employees' expectation. It is necessary for Ardabil Gas Company to adapt and adjust itself to the changing environment dynamically by using appropriate strategies. One of the best reasons for coping with environmental fluctuations is moving the whole organization towards being 
an agile organization. Environmental changes are the major causes of the need for agility because the change is an inherent feature of organizational processes in the modern competitive era (Sherehiy, Karwowski, \& Layer, 2007; Yauch \& Wright, 2007). These days, organizations are witness to changes in their environment during a period of time. Regarding to the situation that prevails in the business world of organizations, organizations had to do changes in their attitudes, knowledge, approaches, procedures, and expected results. This study might have a significant effect on the scientific explanation of strengths and weaknesses of agile organizations and would be influential on improving the outcomes of decision-making process of managers and experts.

\section{Organizational Agility}

The term agile in the dictionary means swift, nimble, active, being able to move fast and easy, and capability to think quickly and with a clever method (Hornby, 2000). Agile organizations are flexible and enjoy high approval rate towards changing market conditions (Hormozi, 2001; Yusuf, Gunasekaran, Adeleye, \& Sivayoganathan, 2004). Agility required quick and effective response towards market needs and requirements (Brown \& Bessant, 2003). Agile organizations have ability to quickly adjust tactics and operations within its supply chain to respond or adapt to changes, opportunities, and threats in its environment (Gligor \& Holcomb, 2012, 2013). An agile organization can rapidly adapt all enterprise elements such as goals, technology, organization, and people to the unpredicted and unexpected changes (Kidd, 1994). Agility refers to the ability of employees to use market knowledge and virtual structure for exploiting profitable opportunities in volatile marketplace (Agarwal, Shankar, \& Tiwari, 2006; Lin, Chiu, \& Tseng, 2006; Naylor, Naim, \& Berry, 1999; Ragin-Skorecka, 2014). Fliedner and Vokurka (1997) defined agility as a successful marketing capability of low-cost qualified products in various quantities at relatively short waiting time that makes more profit for customers. Prince and Kay (2003) stated that agility is a response to the sudden and unexpected changes in the market and meeting the changing needs of customers based on components such as price, characteristic, quality, quantity, and on-time delivery. Gould (1997) asserted that agility means to put aside old methods which in today's environment have low asset turnover and efficiency. Dove (1999) defined agility as an organizational capability to survive and develop in an uncertain and unpredictable business environment. He believed that agility represents management competence and effective use of knowledge in a way that the organization could expand and flourish in 
unpredictable and uncertain business environment. Agility is a collection of capabilities and merits which results in the survival and progress of organization in the business environment (Khoshsima, 2003). Its aim is to line up information technology, employees, and work processes within flexible homogenous system (Shahaei, 2008).

To date, the majority of functional agility studies have been done in the manufacturing and producing domains and so little attention has been paid to the service sector of organizational agility. Furthermore, no special study has been undertaken so far to determine the mediator role of organizational trust and different dimensions of technological intelligence. Agile manufacturing is a relatively new term which was coined by Iacocca institute in 1991. Given the fact that agility is a new concept, there is no widely accepted definition and no consensus on its meaning. Soon after its introduction, the concept of agility in the market and its dimensions became a focal reference for manufacturing system studies (Goldman, Nagel, \& Preiss, 1995; Noaker, 1994; Richards, 1996; Sherehiy \& Karwowski, 2014; Van Assen, Hans, \& Van de Velde, 2001). Many senior researchers focused on the concept of agility on their research such as Goldman and Nagel (1993). They defined agility as market knowledge and virtual cooperation to exploit profitable changes in the marketplace. Following this, Goldman et al. (1995) investigated the effect of trust and empowerment on the agility of an organization. Moreover, Yusuf, Sarhadi, and Gunasekaran (1999) introduced the first conceptual model of agile manufacturing in Liverpool University. Sharifi and Zhang (1999, 2001) presented different articles about the impact of organizational agility dimensions on employee's organizational commitment.

Shahaei (2008) briefly discussed the humanistic dimensions of organizational agility. In his book which is called organizational agility, he described several models of organizational agility and its dimensions. The majority of concepts of this book is derived (extracted) from Sharifi and Zhang $(1999,2001)$ articles and other external experts in the field of agility and did not present anything about localizing of this concept, presenting its local indices, and evaluating agility of employees in the manufacturing organizations. It proposed a dynamic hierarchical model for the measurement of manufacturing agility in the organizations. The results of the study revealed that a number of factors that contributed to agility results, agility capabilities, and the producing chain process of organizations were less affected by environmental drives than agility enablers. Environmental drives like agility enablers, agility capabilities, agility outcomes, and supply chain processes influence organizations. Organizational capabilities presented a favorable context in the organizations which is 
influential in the formation of agility outcomes. The dynamic model of agility is formulated from the final model. The results show that organizational agility has an impact on the environmental changes and the management policies.

A systematic study analyzing the field of management shows that there are no available agility models tackling the field of organizational agility or agility in general. This lack underscores the assumption that the introduced agility model is able to contribute to the field of assessing organizational agility by proposing a new approach that has not been available yet. This shows the real necessity of designing a model of organizational agility against unexpected environmental changes in today's competitive world.

\section{Conceptual Framework of Study}

An overview of this study is presented in the conceptual framework given in Figure 1.

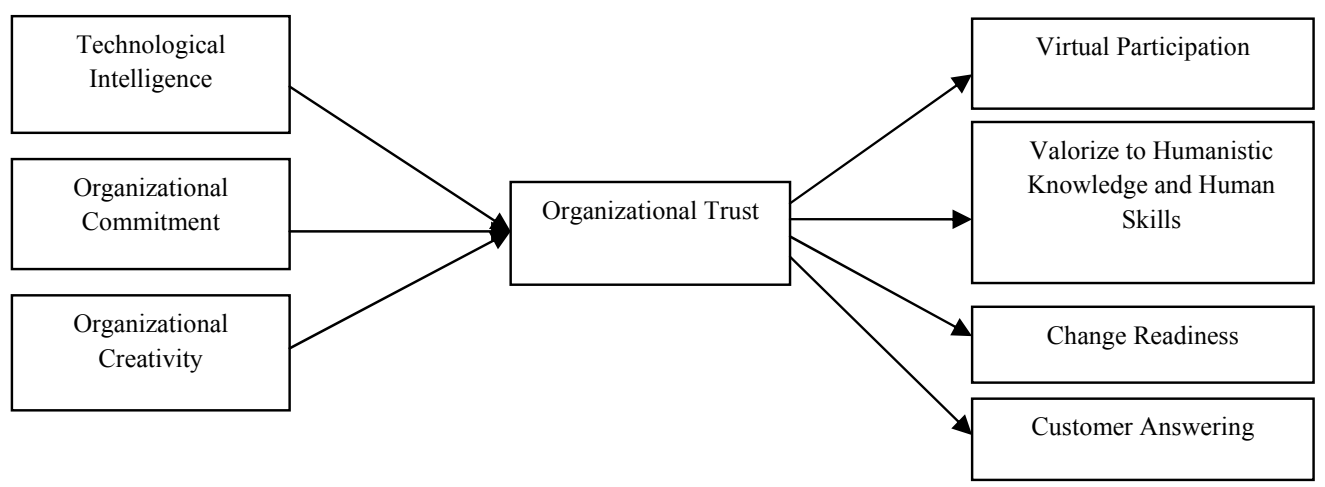

Figure 1. Conceptual model of research

\section{Research Hypotheses}

The research hypotheses that were derived from the conceptual model of research were as follows:

$\mathrm{H}_{1}$ : There is a significant direct relationship between organizational agility and trust.

$\mathrm{H}_{1 \mathrm{a}}$ : There is a significant direct relationship between trust and virtual participation.

$\mathrm{H}_{1 \mathrm{~b}}$ : There is a significant direct relationship between trust and valorizing humanistic knowledge and human skills.

$\mathrm{H}_{1 \mathrm{c}}$ : There is a significant direct relationship between trust and change readiness.

$\mathrm{H}_{1 \mathrm{~d}}$ : There is a significant direct relationship between trust and customer answering.

$\mathrm{H}_{2}$ : Trust adjusts the relationship between organizational agility and technological intelligence. 
$\mathrm{H}_{2 \mathrm{a}}$ : Trust adjusts the relationship between technological intelligence and virtual participation.

$\mathrm{H}_{2 \mathrm{~b}}$ : Trust adjusts the relationship between technological intelligence and valorizing humanistic knowledge and human skills.

$\mathrm{H}_{2 \mathrm{c}}$ : Trust adjusts the relationship between technological intelligence and change readiness.

$\mathrm{H}_{2 \mathrm{~d}}$ : Trust adjusts the relationship between technological intelligence and customer answering.

$\mathrm{H}_{3}$ : Trust adjusts the relationship between organizational agility and organizational commitment.

$\mathrm{H}_{3 \mathrm{a}}$ : Trust adjusts the relationship between organizational commitment and virtual participation.

$\mathrm{H}_{3 \mathrm{~b}}$ : Trust adjusts the relationship between organizational commitment and valorizing humanistic knowledge and human skills.

$\mathrm{H}_{3 \mathrm{c}}$ : Trust adjusts the relationship between organizational commitment and change readiness.

$\mathrm{H}_{3 \mathrm{~d}}$ : Trust adjusts the relationship between organizational commitment and customer answering.

$\mathrm{H}_{4}$ : There is a significant direct relationship between organizational agility and organizational creativity

$\mathrm{H}_{4 \mathrm{a}}$ : Trust adjusted the relationship between organizational creativity and virtual participation.

$\mathrm{H}_{4 \mathrm{~b}}$ : Trust adjusted the relationship between organizational creativity and valorizing humanistic knowledge and human skills.

$\mathrm{H}_{4 \mathrm{c}}$ : Trust adjusted the relationship between organizational creativity and change readiness.

$\mathrm{H}_{4 \mathrm{~d}}$ : Trust adjusted the relationship between organizational creativity and customer answering.

\section{Method}

\section{Participants}

The data of the study was collected in the form of field research. The statistical population of this research consisted of 568 employers, contractors, and subscribers of Ardabil Gas Company. Simple random sampling method was used. Thus, we used the Cochran formula to determine the sample size with limited statistical volume and accordingly the statistical sample size was 200 subjects in current study. 


\section{Instrument}

To collect data, a standardized questionnaire including 56 statements about participants' perceived use of organizational agility was employed. It enjoyed acceptable levels of validity and reliability. It measured respondents' frequency of their actual use by means of a fivepoint Likert scale ranging from strongly disagree ( 1 point) to strongly agree (5 points). Initially, demographic information of the statistical sample including gender, education, marital status, past working experience, and their position was presented in the questionnaire. Table 1 shows the distribution of respondents according to their demographics.

Table 1

Demographic Characteristics of Respondents

\begin{tabular}{|c|c|c|c|}
\hline & Items & Frequency & Percentage \\
\hline \multirow{2}{*}{ Gender } & Male & 168 & $92.8 \%$ \\
\hline & Female & 13 & $8.2 \%$ \\
\hline \multirow[t]{2}{*}{ Marital statues } & Single & 29 & $16 \%$ \\
\hline & Married & 152 & $84 \%$ \\
\hline \multirow[t]{5}{*}{ Education } & High school & 1 & 0.006 \\
\hline & Diploma & 30 & $16.6 \%$ \\
\hline & College (2years) & 54 & $29.8 \%$ \\
\hline & Bachelor & 82 & $45.3 \%$ \\
\hline & Graduate & 14 & $7.7 \%$ \\
\hline \multirow[t]{5}{*}{ Past Working Experience } & Below 5 years & & $18.8 \%$ \\
\hline & $6-10$ years & & $40.3 \%$ \\
\hline & $11-15$ years & & $26.5 \%$ \\
\hline & $16-20$ years & & $3.3 \%$ \\
\hline & $21-25$ years & & \\
\hline \multirow[t]{3}{*}{ Position } & Employee & 394 & $7.7 \%$ \\
\hline & Contractor and & & \\
\hline & & 174 & \\
\hline
\end{tabular}

The questionnaire consisted of five sections which measured the relationship among dependent, independent, and mediator variables of the study and tested the main research hypotheses. In Table 2, the variables, number of questions for each variable, and their respective Cronbach's alphas are presented. 
Table 2

Research Variables, Number of Questions Assigned to each Variable, and their Respective Alpha Coefficients

\begin{tabular}{lccc}
\hline Variables & Number of Items & Range of Items & Reliability Coefficient \\
\hline Technological Intelligence & 7 & $1-7$ & $88 \%$ \\
Organizational Commitment & 6 & $8-13$ & $77 \%$ \\
Organizational Creativity & 11 & $14-24$ & $92 \%$ \\
Organizational Trust & 11 & $25-35$ & $89 \%$ \\
Virtual Participation & 7 & $36-42$ & $86 \%$ \\
Valorize to humanistic knowledge and human skills & 4 & $43-46$ & $78 \%$ \\
Change Readiness & 6 & $47-52$ & $81 \%$ \\
Customer Answering & 4 & $53-56$ & $73 \%$ \\
Total & & & \\
\hline
\end{tabular}

\section{Results}

The result of descriptive statistics summarizes in Table 3. Table 4 shows the results of the K$\mathrm{S}$ test which indicated that the scores of each variable were normally distributed (Asymp.Sig $>0.05$ ). As a result, parametric tests were used for hypothesis testing.

Table 3

Descriptive Statistics of Variables

\begin{tabular}{|c|c|c|c|c|}
\hline Variables & Type of Variables & Number of Items & Mean & SD \\
\hline Technological Intelligence & \multirow[b]{3}{*}{ Independent } & 7 & 3.39 & $80 \%$ \\
\hline Organizational Commitment & & 6 & 4.09 & $65 \%$ \\
\hline Organizational Creativity & & 11 & 3.31 & $81 \%$ \\
\hline Organizational Trust & Mediator & 11 & 3.45 & $70 \%$ \\
\hline \multirow{2}{*}{$\begin{array}{l}\text { Virtual Participation } \\
\text { Valorize to humanistic knowledge and } \\
\text { human skills }\end{array}$} & \multirow[b]{2}{*}{ Dependent } & 7 & 3.57 & $72 \%$ \\
\hline & & 4 & 3.70 & $81 \%$ \\
\hline Change Readiness & & 6 & 3.52 & $73 \%$ \\
\hline Customer Answering & & 4 & 3.69 & $72 \%$ \\
\hline
\end{tabular}

Table 4

One-Sample Kolmogorov-Smirnov Test

\begin{tabular}{lc}
\hline \multicolumn{1}{c}{ Research Variables } & Asymp.Sig. (2-tailed) \\
\hline Technological Intelligence & 0.05 \\
Organizational Commitment & 0.05 \\
Organizational Creativity & 0.59 \\
Organizational Trust & 0.62 \\
Organizational Agility & 0.64 \\
\hline
\end{tabular}

Pearson's product moment correlation coefficient was used for identifying the relationship between variables and investigating the possibility of each hypothesis. According to Table 5, Pearson's correlation coefficient was less than $25 \%$ indicating that the relationship between two variables was weak. Likewise, the correlation coefficient ranging from $6 \%$ to $25 \%$, 
showing a statistically average relationship between variables and the coefficient greater than $6 \%$ revealed a strong positive linear relationship between variables. By doing correlation test, $p$-values were acquired at $99 \%$ confidence level. This indicated that there was positive significant relationship among variables of the study with respect to positive sign of correlation coefficient.

Table 5

Pearson's Product-moment Correlations between Dependent and Independent Variables

\begin{tabular}{llllll}
\hline Variables & 1 & 2 & 3 & 4 & 5 \\
\hline Technological Intelligence & $1.00 * *$ & 1.00 & & & \\
Organizational Commitment & $0.57^{* *}$ & $0.66^{* *}$ & 1.00 & & \\
Organizational Creativity & $0.74^{* *}$ & $0.66^{* *}$ & $0.72^{* *}$ & 1.00 & $0.66^{* *}$ \\
Organizational Trust & $0.67^{* * *}$ & $0.57^{* *}$ & $0.62^{* *}$ & 1.00 \\
Organizational Agility & $0.61^{* *}$ & & & \\
\hline
\end{tabular}

$* * p<0.01 * p<0.05$

\section{Assessment of the Fitness of the Conceptual Model}

To evaluate the impact of technological intelligence on organizational agility and to test research hypotheses, confirmatory factor analysis was performed using path analysis by LISREL software. The conceptual model of the study is discussed below in the two modes of significance coefficients and the standard estimation as shown in Figures 1 and 2. Table 6 shows the conceptual model fitness for technological intelligence.

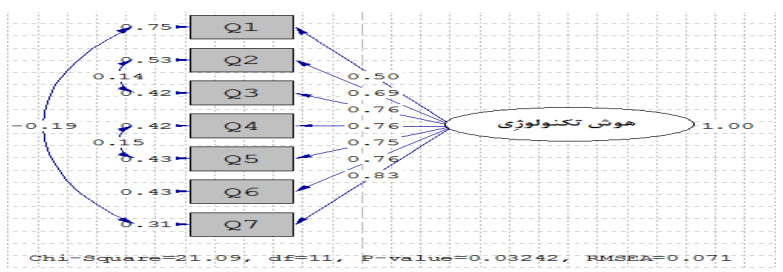

Figure 1. Structural equation modeling of technological intelligence (standardized estimation)

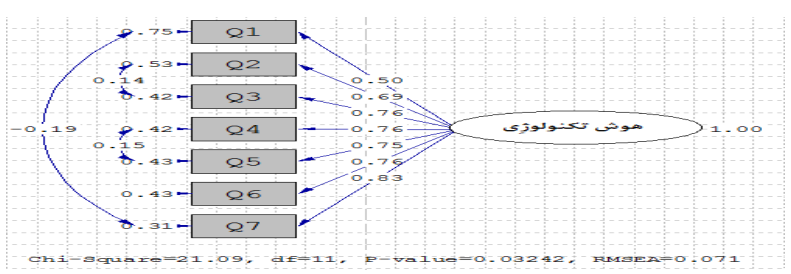

Figure 2. Structural equation modeling of technological intelligence (significance of coefficients)

Table 6

Indicators of the Conceptual Model Fitness for Technological Intelligence

\begin{tabular}{lcccc}
\hline Indicators & RMSEA & p-value & df & Chi-Square \\
\hline Index Values & 0.07 & 0.03 & 11 & 21.09 \\
\hline
\end{tabular}


Before testing the research hypotheses, we should first examine the overall fitness of the conceptual model. The best indicator in LISREL is X2 (Chi-Square) divided by df. The smaller the resulting value than three do, the more fitted the model. This value for the conceptual model of technological intelligence was 1.91, showing an acceptable level of the fitness of the model. The other indicator is RMSEA (Mean square of model errors) which is constructed based on the model errors. When the value of this indicator is less than 0.05 , it shows that the model is well fitted. When this value is between 0.05 and 0.07 , the fitness is acceptable, between 0.08 and 0.1 , the fitness is medium, and if it is greater than one the fitness is poor. The value of RMSEA for the conceptual model used in the present study was 0.07, which showed that the fitness of the model is acceptable with a $90 \%$ confidence interval. Concerning the $p$-value, some scholars believe that it should be higher than 0.5 while others suggest values less than 0.5 . In general, there is no consensus on this index.

As shown in Figures 3 and 4, the overall statistic indices used in organizational commitment suggest that the model fitted the data well. The chi-square statistic was too small $\left(x^{2}=0.02, \mathrm{df}=6\right)$ to reject the null hypothesis of good fit $(p=0.33)$. In this study, the acceptable level of significance (factor loading) in the standardized model was higher than 0.3 , and t-values were either higher than 1.96 or lower than -1.96 . The results of the confirmatory factor analysis in Figure 3 and 4 reveled that all fit indices were considered within acceptable fit level of organizational commitment.

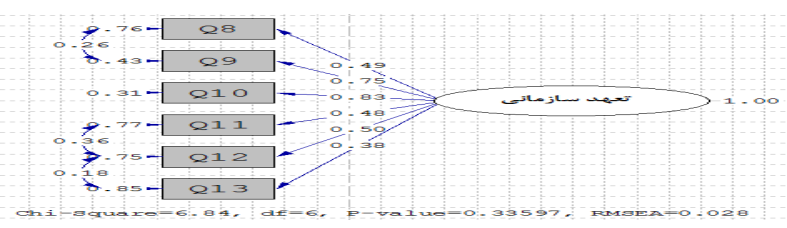

Figure 3. Structural equation modeling of organizational commitment (standardized estimation)

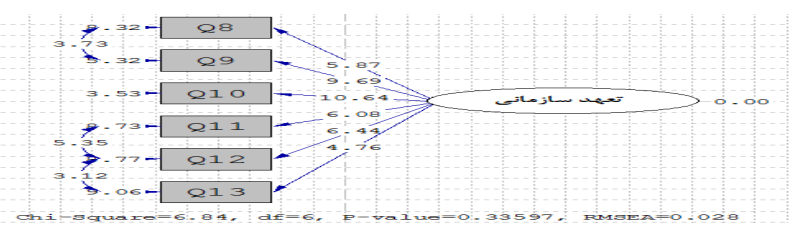

Figure 4. Structural equation modeling of organizational commitment (significance of coefficients) 
Table 7

Indicators of the Conceptual Model Fitness for Organizational Commitment

\begin{tabular}{ccccc}
\hline Indicators & RMSEA & p-value & df & Chi-Square \\
\hline Index Values & 0.02 & 0.33 & 6 & 6.48 \\
\hline
\end{tabular}

As the path diagram of Figures 3 and 4 shows, the mean square root of approximate errors $($ RMSEA $=0.06)$, Chi-square (6.48), $p$-value (0.33), and df (6) were considered for the assessment of model goodness of fit. All factor loadings of constructs were tested at $1 \%$ error level, they were significant at the $99 \%$ confidence level, and related structures of measurement were able to make a significant contribution. This result showed that the fit values of the model were an acceptable and desirable level.

As shown in Figures 5 and 6, the results showed that all the related indices had acceptable amount of t-value (more than 1.96) and factor loading (more than 0.3) except for item 15. Therefore, they were good indices for organizational commitment and just item 15 was omitted from the questionnaire due to its low t-value.

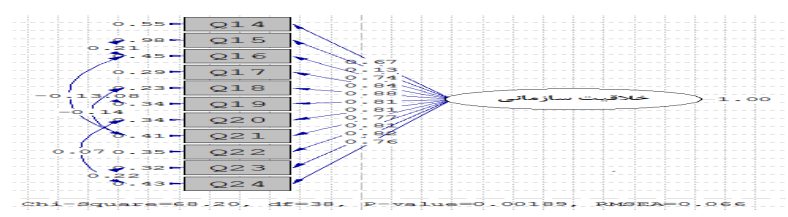

Figure 5. Structural equation modeling of organizational creativity (standardized estimation)

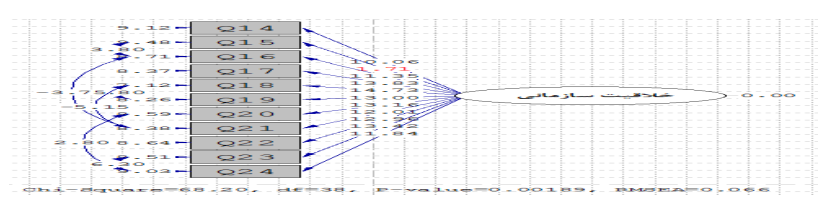

Figure 6. Structural equation modeling of organizational creativity (significance of coefficients)

Table 8

Indicators of the Conceptual Model Fitness for Organizational Creativity

\begin{tabular}{ccccc}
\hline Indicators & RMSEA & $\mathrm{p}$-value & df & Chi-Square \\
\hline Index Values & 0.06 & 0.00 & 38 & 68.2 \\
\hline
\end{tabular}

Table 8 also showed the mean square root of approximate errors (RMSEA=0.06), Chisquare (6.48), $p$-value (0.33), and $\mathrm{df}(6)$ for the assessment of model goodness of fit. Figures 
2 and 3 presented the t-values and factor loadings for each question. The results indicated that organizational trust was the significant factor affecting the organizational agility. Also, they showed that all the related indices had acceptable amount of t-value (more than 1.96) and factor loading (more than 0.3 ) except for item 34.

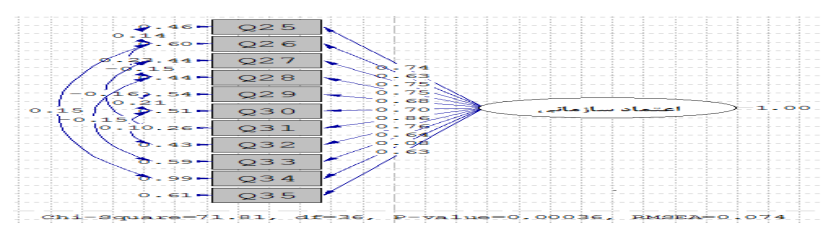

Figure 7. Structural equation modeling of organizational trust (standardized estimation)

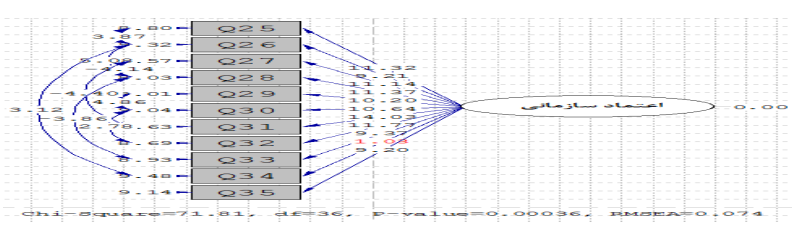

Figure 8. Structural equation modeling of organizational trust (significance of coefficients)

Table 9 displays the measures of fit for organizational commitment. These measures suggested that the overall statistic indices used in organizational commitment fitted the data well.

Table 9

Indicators of the Conceptual Model Fitness for Organizational Trust

\begin{tabular}{ccccc}
\hline Indicator & RMSEA & p-value & df & Chi-Square \\
\hline Index Values & 0.07 & 0.00 & 36 & 71.81 \\
\hline
\end{tabular}

As shown in Figures 9 and 10, the results showed that all the related indices had acceptable amount of t-value (more than 1.96) and factor loading (more than 0.3). The mean square root of approximate errors (RMSEA $=0.07)$, Chi-square $(328.5), p$-value $(0.00)$, and df (157) were considered for the assessment of model goodness of fit (Table 10). 


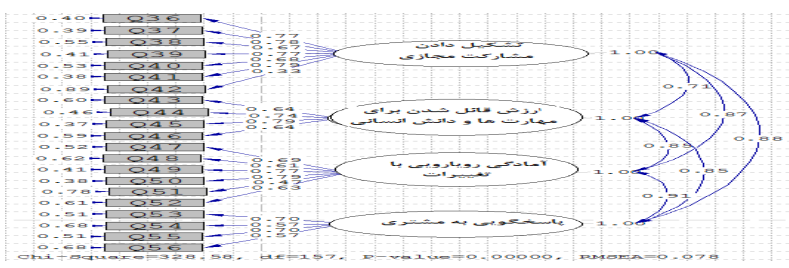

Figure 9. Structural equation modeling of organizational agility (standardized estimation)

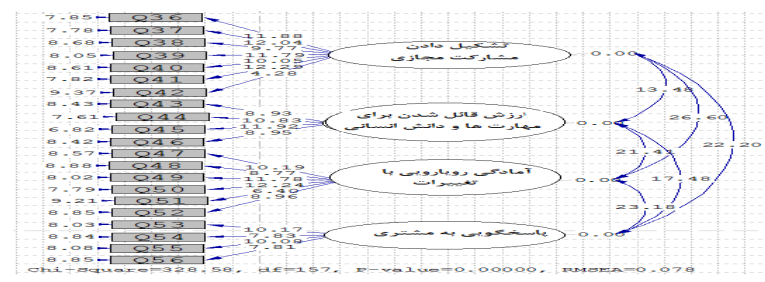

Figure 10. Structural equation modeling of organizational agility (significance of coefficients)

Table 10

Indicators of the Conceptual Model Fitness for Organizational Agility

\begin{tabular}{ccccc}
\hline Indicator & RMSEA & p-value & df & Chi-Square \\
\hline Index Values & 0.07 & 0.00 & 157 & 328.5 \\
\hline
\end{tabular}

\section{Structural Equation Modeling (SEM)}

After confirming the goodness of fit for the measurement models in the first step, the second step was to test the hypotheses using SEM. The path coefficient and T-statistics between variables were presented in Table 11. It showed that organizational trust had a positive significant relationship with the organizational agility. Therefore, the first hypothesis was confirmed. The amount of coefficient of determination $\left(\mathrm{R}^{2}\right)$ was equal to 0.57 . This ratio shows the predictive ability of dependent variable by independent variable or variables. Therefore, organizational trust predicted 57 percents of variations related to organizational agility. The second row of Table 11 presents information about the second main hypothesis. It revealed that the second hypothesis was also confirmed. Therefore, organizational trust adjusted the relationship between technological intelligence and organizational agility based on the path coefficient $(\beta=0.33)$ and t-statistics $(t=3.51)$. The findings $(\beta=0.28$; $t$-statistics $\left.=2.46 ; \mathrm{R}^{2}=0.61\right)$ confirmed the third main hypothesis which organizational trust might adjust the relationship between organizational commitment and organizational agility. The amount of coefficient of determination $\left(\mathrm{R}^{2}\right)$ was equal to 0.61 . Meanwhile, the results indicated that the fourth main hypothesis which demonstrated the relationship between 
organizational agility $\left(\beta=0.69\right.$, t-statistics $\left.=8.97 ; \mathrm{R}^{2}=0.47\right)$ and organizational agility was confirmed.

Table 11

Path Coefficients, T-statistics, and Coefficient of Determinations of the Variables for Analyzing Main Hypotheses

\begin{tabular}{cccc}
\hline Variables & Path Coefficient $(\beta)$ & T-statistics & Coefficient of Determination $\left(\mathrm{R}^{2}\right)$ \\
\hline $\begin{array}{c}\text { Organizational Trust } \\
\text { Technological Intelligence }\end{array}$ & 0.76 & 9.78 & 0.57 \\
Organizational Commitment & 0.33 & 3.51 & 0.61 \\
Organizational Creativity & 0.28 & 2.46 & 0.61 \\
& 0.69 & 8.97 & 0.47 \\
$* * p<0.01 * p<0.05$ & & &
\end{tabular}

Tables 12 and 13 summarize the findings for each hypothesis. All sub-hypotheses were tested by SEM and confirmed except for $\mathrm{H}_{2 \mathrm{~b}}, \mathrm{H}_{4 \mathrm{a}}, \mathrm{H}_{4 \mathrm{~b}}, \mathrm{H}_{4 \mathrm{c}}$, and $\mathrm{H}_{4 \mathrm{~d}}$. Therefore, these items should be discarded from the questionnaire.

Table 12

Path Coefficients, T-statistics, and Coefficient of Determinations of the Variables for Analyzing Sub-hypotheses

\begin{tabular}{|c|c|c|c|c|c|c|c|c|c|}
\hline \multirow{3}{*}{$\begin{array}{l}\text { Independent Variables } \\
\text { Dependent Variables }\end{array}$} & \multirow{2}{*}{\multicolumn{3}{|c|}{ Technological Intelligence }} & \multirow{2}{*}{\multicolumn{3}{|c|}{ Organizational Commitment }} & \multirow{2}{*}{\multicolumn{3}{|c|}{ Organizational Creativity }} \\
\hline & & & & & & & & & \\
\hline & $\beta$ & T Statistics & $\mathrm{R}^{2}$ & $\beta$ & T Statistics & $\mathrm{R}^{2}$ & $\beta$ & T Statistics & $\mathrm{R}^{2}$ \\
\hline Virtual Participation & 0.39 & $4.13^{* * *}$ & 0.65 & 0.46 & $5.60^{* * *}$ & 0.67 & 0.12 & 1.24 & 0.62 \\
\hline $\begin{array}{l}\text { Valorize to humanistic } \\
\text { knowledge and human } \\
\text { skills }\end{array}$ & 0.13 & 1.16 & 0.48 & 0.39 & $4.59^{* *}$ & 0.66 & -0.03 & -0.24 & 0.51 \\
\hline Change Readiness & 0.25 & $2.68^{* * *}$ & 0.72 & 0.40 & $4.79^{* *}$ & 0.68 & 0.09 & 0.92 & 0.75 \\
\hline Customer Answering & 0.25 & $2.05^{*}$ & 0.54 & 0.58 & $6.64^{* *}$ & 0.57 & -0.12 & -0.97 & 0.58 \\
\hline
\end{tabular}

Table 13

Path Coefficient and the Results of Significance Tests

\begin{tabular}{ccccc}
\hline $\begin{array}{c}\text { Hypothesi } \\
\text { Number }\end{array}$ & $\begin{array}{c}\text { Path Coefficient } \\
(\beta)\end{array}$ & T Statistics & Significance & $\begin{array}{c}\text { Hypothesis } \\
\text { Testing }\end{array}$ \\
\hline $\mathrm{H}_{01}$ & 0.76 & 9.78 & There is a significant positive relationship & Confirmed \\
$\mathrm{H}_{1 \mathrm{a}}$ & 0.81 & 10.14 & There is a significant positive relationship & Confirmed \\
$\mathrm{H}_{1 \mathrm{~b}}$ & 0.73 & 6.99 & There is a significant positive relationship & Confirmed \\
$\mathrm{H}_{1 \mathrm{c}}$ & 0.88 & 9.20 & There is a significant positive relationship & Confirmed \\
$\mathrm{H}_{1 \mathrm{~d}}$ & 0.78 & 7.69 & There is a significant positive relationship & Confirmed \\
$\mathrm{H}_{02}$ & 0.33 & 3.51 & There is a significant positive relationship & Confirmed \\
$\mathrm{H}_{2 \mathrm{a}}$ & 0.39 & 4.13 & There is a significant positive relationship & Confirmed \\
$\mathrm{H}_{2 \mathrm{~b}}$ & 0.13 & 1.16 & There is no statistically significant relationship & Rejected \\
$\mathrm{H}_{2 \mathrm{c}}$ & 0.25 & 2.68 & There is a significant positive relationship & Confirmed \\
$\mathrm{H}_{2 \mathrm{~d}}$ & 0.25 & 2.05 & There is a significant positive relationship & Confirmed
\end{tabular}




\begin{tabular}{lllll}
$\mathrm{H}_{03}$ & 0.28 & 2.46 & There is a significant positive relationship & Confirmed \\
$\mathrm{H}_{3 \mathrm{a}}$ & 0.46 & 5.60 & There is a significant positive relationship & Confirmed \\
$\mathrm{H}_{3 \mathrm{~b}}$ & 0.39 & 4.59 & There is a significant positive relationship & Confirmed \\
$\mathrm{H}_{3 \mathrm{c}}$ & 0.40 & 4.79 & There is a significant positive relationship & Confirmed \\
$\mathrm{H}_{3 \mathrm{~d}}$ & 0.58 & 6.64 & There is a significant positive relationship & Confirmed \\
$\mathrm{H}_{04}$ & 0.69 & 8.97 & There is a significant positive relationship & Confirmed \\
$\mathrm{H}_{4 \mathrm{a}}$ & 0.12 & 1.24 & There is no statistically significant relationship & Rejected \\
$\mathrm{H}_{4 \mathrm{~b}}$ & -0.03 & -0.24 & There is no statistically significant relationship & Rejected \\
$\mathrm{H}_{4 \mathrm{c}}$ & 0.09 & 0.92 & There is no statistically significant relationship & Rejected \\
$\mathrm{H}_{4 \mathrm{~d}}$ & -0.12 & -0.97 & There is no statistically significant relationship & Rejected \\
\hline
\end{tabular}

\section{Discussion and Conclusion}

The purpose of this study was to provide a model for analyzing organization agility and presenting a comprehensive model for Ardabil Gas Company. The findings revealed that the variables such as technological intelligence, organizational commitment, organizational creativity, and organizational trust had significant effect on organizational agility and Ardabil Gas Company should increase its agility capabilities. In this study, technological intelligence, organizational commitment, organizational creativity, and organizational trust had influence on organizational agility and all of them should be used in order to build the agility in different organizations. Considering the second main hypothesis, there was a significant direct relationship between organizational trust and organizational agility. For the purpose of developing and internalizing the culture of organizational trust among the employees of Ardabil Gas Company within the organization, the management should create a condition in which the employees feel secure in their personal relationships with their managers and coworkers. Both managers and employees should be aware of their mutual expectations in order to build trust and a positive atmosphere. Conducting continuous communication with different organizations such as universities and research and education centers, using different types of models for showing the process of converting the raw data into the meaningful one for intelligence cycle in decision making, developing technology in the Gas Company, proving information about strengths, weaknesses, threats and opportunities, and science and technological development are critical success factors affecting the performance of Ardabil Gas Company.

In the realm of organizational commitment, personal identification occurs through organization when the individual values are consistent with the organizational values. It is therefore necessary for the organizations to present their values and expectations in advance in either oral or written forms to build an intrinsic pride in their employees. The employees 
have a better sense of belonging to the organization which pays more attention to its employees' career and family issues. Thus, it is essential that the managers and the targeted unites pay more attention to human resources issues in order to build a sense of belonging.

The employees, who want to feel supported by their organization, create a sense of duty in response to perceived organizational support. Therefore, it is recommended that the managers and targeted unites try hard to induce a sense of duty towards the work in their employees by supporting them. Furthermore, Ardabil Gas Company should proceed to the building of a creative space. A creativity-stimulating atmosphere means that the managers have to cultivate a stimulating atmosphere and be ready to listen to everyone's new ideas in their organization. In fact, the organization needs to search these kinds of thoughts and does not wait for the next new idea. Thus, if we want to build creativity, we should welcome suggestions that are based on current changes. The main criterion is whatever the manager does on behalf of the firm in reality not what he says. Every single thought should be analyzed and should be rejected by providing a convincing explanation for rejection of it. They can encourage individuals to plan their activities by allocating time to build creative thinking. While the employees should address the actual issues of the organization and its daily issues, we can also provide opportunities for some individuals to become creative. It is better to provide some ways on how to propose suggestions so that the employees believe that their managers need their ideas and a key prerequisite for such beliefs is that managers seriously check all suggested ideas seriously. Creating a special unit for creativity, building a mechanism for progressive evaluation of creative activities, encouraging the employees to be innovative in motivational issues, creating systematic approaches for continuous improvement, establishing new management systems for working processes among the employees, updating dynamic educational systems, updating knowledge of employees about technology, software and equipment, assigning a special place for think tank in order to provide new ideas, and forming knowledge innovations are important factors affecting organization's agility. The present study is not free from limitations. The very first limitation of the study relates to using only Ardabil Gas Company's employees and excluding other companies. Second, this study ignored other dimensions that may be considered as part of a broadened conceptualization of organizational agility construct. Third, this study used a questionnaire to elicit information from employees. The use of other methods such as observation and interview could have increased the validity of data. The most important contribution of this study is that it generates awareness of what constitutes organizational 
agility and creates an understanding about the complexity of organizational agility.

Furthermore, it may serve a reference frame to implement a systematic and well-directed approach for improvements and continuous assessments of actions taken.

\section{References}

Agarwal, A., Shankar, R., \& Tiwari, M. K. (2006). Modeling the metrics of lean, agile and leagile supply chain: An ANPbased approach. European Journal of Operational Research, 73, 211- 225.

Brown, S., \& Bessant, J. (2003). The manufacturing strategy-capabilities links in mass customization and agile manufacturing: An exploratory study. International Journal of Operations \& Production Management, 23(7), 707-730.

Dove, R. (1999). Knowledge management, responsibility, and the agile enterprise. Journal of Knowledge Management, 3(1), $18-35$.

Eisenhardt, K. M., \& Martin, J. A. (2000). Dynamic capabilities: What are they? Strategic Management Journal, 21, 11051121.

Fliedner, G., \& Vokurka, R. (1997). Agility: The next competitive weapon. APICS: The Performance Advantage, 7(1), 56 59.

Gligor, D. M., \& Holcomb, M. C. (2012). Antecedents and consequences of supply chain agility: Establishing the link to firm performance. Journal of Business Logistics, 33(4), 295-308.

Gligor, D. M., \& Holcomb, M. C. (2013). Multidisciplinary approach to supply chain agility: Conceptualization and scale development . Journal of Business Logistics, 34(2), 94-108.

Goldman, S. L., Nagel, R. N., Preiss, K., \& Dove, R. (1991). Iacocca institute: $21^{\text {st }}$ Century manufacturing enterprise strategy:An industrial led view. Bethlehem, PA. : Iacocca Institute.

Goldman, S. L., \& Nagel, R. N. (1993). Management, technology, and agility: The emergence of a new era in manufacturing. International Journal of Technology Management, 2(8), 18-38.

Goldman, S. L., Nagel, R. N., \& Preiss, K. (1995). Agile competitors and virtual organizations: Strategies for enriching the customer ( $1^{\text {st }}$ ed.). New York: Van Nostrand Reinhold.

Gould, P. (1997). What is agility? IEE Manufacturing Engineering, 76(1), 28-31.

Grant, R. M. (1996). Prospering in dynamically competitive environments: Organizational capability as knowledge integration. Organization Science, 7(4), 375-387.

Hormozi, A. M. (2001). Agile manufacturing: The next logical step. Benchmarking: An International Journal, 8(2), 132 143.

Hornby, A. S. (2000). Oxford advanced learners dictionary of current English ( $6^{\text {th }}$ ed.). UK: Oxford University Press.

Khoshsima, G. (2003). A model for measuring organizational agility in Iran television manufacturing industry: A fuzzy logic framework. Proceedings of International Engineering Management Conference, USA.

Kidd, P. T. (1994). Agile manufacturing: Forging new frontiers. Reading, MA: Addison-Wesley.

Lin, C. T., Chiu, H., \& Tseng, Y. H. (2006). Agility evaluation using fuzzy logic. International Journal of Production Economics, 101, 353-368.

Naylor, J. B., Naim, M. M., \& Berry, D. (1999). Leagility: Interfacing the lean and agile manufacturing paradigm in the total supply chain. International Journal of Production Economics, 62(1/2), 107-118.

Nijssen, M., \& Paauwe, J. (2012). HRM in turbulent times: How to achieve organizational agility? The International Journal of Human Resource Management, 23(16), 3315-3335.

Noaker, P. M. (1994). The search for agile manufacturing. Manufacturing Engineering, 113(5), 5 -11.

O’Driscoll, M. P., \& Randall, D. M. (1999). Perceived organizational support, satisfaction with rewards, employee job involvement and organizational commitment. Applied Psychology: An International Review, 48(2), 197-209.

Prince, J., \& Kay, J. M. (2003). Combining lean and agile characteristics: Creation of virtual groups by enhanced production flow analysis. International Journal of Production Economics, 85, 305-318.

Ragin-Skorecka, K. (2014). Agile enterprise: A human factors perspective. Human Factors \& Ergonomics in Manufacturing \& Service Industries, $0(0), 1-11$.

Richards, C. (1996). Agile manufacturing: Beyond lean? Production \& Inventory Management Journal, 2, 60-64.

Shahaei, B. (2008). An agility paradigm: Definitions, characteristics and implications. Tadbir Journal, 194, 14-18.

Sharifi, H., \& Zhang, Z. (1999). A methodology for achieving agility in manufacturing organizations: An introduction. International Journal of Production Economics, 62(1), 7-22.

Sharifi, H., \& Zhang, Z. (2001). Agile manufacturing in practice application of a methodology. International Journal of Operations \& Production Management, 21(5/6), 772-779.

Sherehiy, B., \& Karwowski, W. (2014). The relationship between work organization and workforce agility in small manufacturing enterprises. International Journal of Industrial Ergonomics, 44, 466-473.

Sherehiy, B., Karwowski, W., \& Layer, J. K. (2007). A review of enterprise agility: Concepts, frameworks and attributes. International Journal of Industrial Ergonomics, 37(5), 445-460.

Van Assen, M. F., Hans, E. W., \&Van de Velde, S. L. (2001). An agile planning and control framework for customer-order driven discrete parts manufacturing environments. International Journal of Agile management Systems, 2(1), 16-23. 
Winby, S., \& Worley, C. G. (2014). Management processes for agility, speed, and innovation. Organizational Dynamics, 43 , 225-234.

Yauch, C. A., \& Wright, P. (2007). Studying the performance and agility of individuals using cooperative and competitive incentives. Human Factors \& Ergonomics in Manufacturing, 17(2), 105-115.

Yusuf, Y. Y., Sarhadi, M., \& Gunasekaran, A. (1999). Agile manufacturing: The drivers, concepts, and attributes. International Journal of Production Economics, 62, 33-43.

Yusuf, Y., Gunasekaran, A., Adeleye, E. O., \& Sivayoganathan, K. (2004). Agile supply chain capabilities: Determinants of competitive objectives. European Journal of Operational Research, 159(2), 379-392.

Zain, M., Rose, R. C., Abdullah, I., \& Masrom, M. (2005). The relationship between information technology acceptance and organizational agility in Malaysia. Information \& Management, 42, 829-839. 